\title{
Tax Incentives, Material Inputs, and the Supply Curve for Capital Equipment
}

\author{
Karl Whelan \\ Division of Research and Statistics \\ Federal Reserve Board *
}

May 4, 1999

\begin{abstract}
The slope of the supply curve for capital equipment has important implications for the macroeconomics of investment and the effects of tax reform on capital accumulation. Goolsbee (1998) has used changes in investment tax incentives to identify whether this supply curve is significantly upward-sloping and has concluded that it is. This paper shows that investment tax incentives are a poor instrument for identifying this supply curve because they are spuriously correlated with supply shocks for equipment producers. Once input costs for equipment producers are controlled for, there is no evidence of a relationship between tax incentives and equipment prices. In fact, the evidence favors a flat supply curve interpretation.
\end{abstract}

${ }^{*}$ Mail Stop 80, 20th and C Streets NW, Washington DC 20551. Email: kwhelan@frb.gov. I wish to thank, without implicating, Darrel Cohen, Spencer Krane, Stacey Tevlin, and, in particular, Austan Goolsbee for comments on a previous draft. The views expressed in this paper are those of the author and do not necessarily reflect the views of the Board of Governors or the staff of the Federal Reserve System. 
Despite theoretical predictions that the cost of capital should have an important effect on investment, traditionally empirical research has found this effect to be relatively small. One potential explanation for this pattern has been that these estimates are biased downward due to the endogeneity of interest rates: The monetary authorities tend to lower interest rates in response to negative shocks to investment. Thus, a popular alternative approach to identifying the effect of user cost on investment has been to instead focus on variations in the tax component of the cost of capital. However, the evidence on the effect of tax incentives has been mixed. While some studies, such as Cummins, Hassett, and Hubbard (1994) have argued that, around major tax reforms, the elasticity of investment with respect to the tax portion of the cost of capital is about $-2 / 3$ or larger, estimates based on time series regressions, such as those of Peter K. Clark (1993), have been far smaller, on the order of no more than -0.4 .

In an important contribution, Austan Goolsbee (1998) has provided a potential explanation for why tax incentives may impart only a limited stimulus to investment: If the supply curve for capital equipment is sufficiently upward-sloping, then the outward shift in the demand curve for equipment induced by investment tax incentives could mainly result in higher equipment prices rather than higher quantities. In testing this hypothesis, Goolsbee's empirical analysis focused on the effect on equipment prices of tax incentives and revealed a robust relationship consistent with a strongly upward-sloping supply curve for capital equipment. This result has important consequences not only for the macroeconomics of investment but also for public finance since the proponents of fundamental tax reform often stress the beneficial effects on capital formation of improved tax incentives for investment. Interestingly, however, another detailed empirical study of supply curves by John Shea (1993) reports downward-sloping supply curves for the two capital good industries in its sample (construction machinery and aircraft). An important difference between these two studies is their choice of "identifying" demand shock used to trace out the supply curve. Goolsbee uses measures of investment tax incentives while Shea's demand instruments are chosen from a detailed search for variables that satisfy two critera, one indicating they are an important component of an industry's demand, the other suggesting they are likely to have a low correlation with the industry's supply shocks.

This paper re-examines the supply curve for capital equipment and concludes that tax incentives are a poor instrument for identifying this curve because they substantially fail Shea's second criterion of low correlation with supply shocks. Specifically, I show that 
starting in 1974-75 and continuing until the early 1980s, relative prices for almost all types of equipment rose at a fast pace (or faster than their trend rate) and then for some years after this period, this pattern was reversed. Since the investment tax credit was strengthened in the mid-1970s and eliminated in 1986 this resulted in a correlation between equipment prices and measures of investment tax incentives, implying a strongly upward-sloping supply curve. However, I show that that these gyrations in equipment prices were far more highly correlated with movements in prices of intermediate inputs (energy and materials) and that once these supply shocks are controlled for, there is no evidence of a relationship between equipment prices and tax incentives. In fact, I argue that the response of equipment prices to these supply shocks is instead broadly consistent with a flat supply curve.

Section 1 gives a brief theoretical discussion. Section 2 presents the evidence on the behavior over time of equipment prices, the investment tax credit, and intermediate input prices for equipment producers. Section 3 contains the basic econometric results, which extend Goolsbee's analysis to account for the effect of intermediate input prices. Section 4 examines whether the observed fluctuations in intermediate input prices for equipment producers could be related to changes over time in the tax treatment of investment. Section 5 concludes.

\section{Supply, Demand, and Equipment Prices}

As I will focus below on the effect of materials prices on the price of equipment, consider the case of firms producing capital equipment with materials being the only variable input $\left(Q=M^{\alpha}\right)$ implying a marginal cost curve of the form $\frac{c}{\alpha} Q^{\frac{1}{\alpha}-1}$, where $c$ is the price of the materials. Suppose there is a large number of firms, $n$, producing equipment, each taking the price, $p$, as given and determining their supply by setting marginal cost equal to this price. This implies an equipment supply curve of the form

$$
Q^{S}=n\left(\frac{\alpha p}{c}\right)^{\frac{\alpha}{1-\alpha}}
$$

Suppose now the demand curve for equipment is

$$
Q^{D}=(p(1-s))^{-\beta}
$$

where $s$ summarizes investment tax incentives. ${ }^{1}$ Setting supply equal to demand and solving

\footnotetext{
${ }^{1} \mathrm{~A}$ more complete model of equipment demand would of course also include interest rates, depreciation,
} 
for the equilibrium price gives

$$
p=\left(\left[\frac{1}{n} \frac{1}{(1-s)^{\beta}}\left(\frac{c}{\alpha}\right)^{\frac{\alpha}{1-\alpha}}\right]\right)^{\frac{1-\alpha}{\alpha+\beta(1-\alpha)}}
$$

Re-written in terms of logs we get:

$$
\log (p)=-\frac{(1-\alpha)}{\alpha+\beta(1-\alpha)} \log (n)-\frac{\beta(1-\alpha)}{\alpha+\beta(1-\alpha)} \log (1-s)+\frac{\alpha}{\alpha+\beta(1-\alpha)} \log \left(\frac{c}{\alpha}\right)
$$

Consider now the two extreme cases of $\beta=1$ (unit elastic investment demand) and $\beta=0$ (price inelastic investment demand). When $\beta=1$ the elasticities of the price of equipment with respect to the tax term and the price of materials are $1-\alpha$ and $\alpha$ respectively. When $\beta=0$ the elasticity with respect to the tax term is zero while the elasticity with respect to the materials price is 1 or, more accurately, a coefficient equal to materials' share in total variable cost, here assumed to be 1 .

Of course, if the equipment industry is better approximated by free entry and so the number of firms is not fixed, then zero profits implies a price of equipment that is independent of tax incentives. In this case, we have

$$
\log (p)=\log \left(\frac{F^{1-\alpha}}{\alpha^{\alpha}-\alpha}\right)+\alpha \log c
$$

where $F$ measures fixed costs. The regressions below suggest that this competitive price equation appears to fit the data well. Note that, when firms are price takers, then $\alpha$ can

be observed as the ratio of total materials costs to the value of output since $\frac{c M}{p Q}=\alpha$ is a first-order condition. The estimated elasticities with respect to material prices reported in Section 3 reveal coefficients similar to this observed ratio.

\section{The Data}

\subsection{The Relative Price of Equipment}

Figures $1 \mathrm{~A}$ and $1 \mathrm{~B}$ show the behavior of equipment prices relative to the GDP deflator over the period 1959 to 1997. Through 1994, these data can be obtained from Table 7.8 of Department of Commerce (1998a); data from 1995-97 can be found in Department of and so on. However, since we are only focusing on prices and taxes, this is a reasonable simplification for our purposes. 
Commerce (1998b). This sample is longer than the 1959-1988 sample used by Goolsbee, which was taken from Department of Commerce (1993) and since many of these series are based on hedonic adjustment methodologies that have changed over time, one cannot exactly replicate Goolsbee's results with this data set. However, as I show below, the qualitative features of his results can still be obtained from these data.

Two patterns emerge strongly from Figures 1A and 1B. First, many of the relative prices have substantial trends over time. While some types of equipment appear to have upward trends, more noticeable are the downward trends for computing equipment and other "high-tech" categories such as communications equipment and instruments. The decline in the relative price of capital equipment is, of course, due to the radical improvements in productivity in high-tech industries, a well-known fact that has featured prominently in recent attempts to explain the process of aggregate productivity growth. ${ }^{2}$ Thus, it is necessary to control for these long-term trends and, in the regressions below, we follow Goolsbee in including a time trend on the right-hand-side of the relative price regressions.

The second noticeable pattern is that, for a wide range of equipment types, there was a sharp rise in relative prices beginning in 1974-75 and continuing until the early to mid-1980s. Even those types of equipment that did not see large increases in relative prices appeared to rise relative to their trend level: After detrending using a simple regression of the log of the relative price on a time trend, 20 of the 22 relative equipment prices rose substantially beginning with the 1974-75 period with most falling back again at varying speeds during the 1980s. However, this simple characterization masks a significant diversity in terms of the magnitude of these swings. For example, while the timing of the swings in the relative prices of construction machinery and mining machinery are similar, the detrended relative price of the former increased 19 percent between 1974 and 1980 while the increase for the latter was 37 percent.

\subsection{Equipment Prices and the ITC}

Figures $2 \mathrm{~A}$ and $2 \mathrm{~B}$ compare the detrended relative equipment prices with the good-specific rates for the investment tax credit (ITC), taken from Gravelle (1994); the detrended relative equipment prices are the solid lines and the ITCs are the dashed lines. The ITC was first introduced in 1962 and set at varying rates for different types of equipment. The credit was

\footnotetext{
${ }^{2}$ See for instance, Greenwood, Hercowitz, and Krussell (1997).
} 
Figure 1A

Equipment Prices Relative to the GDP Deflator

Indexes (1992=1)

Furniture

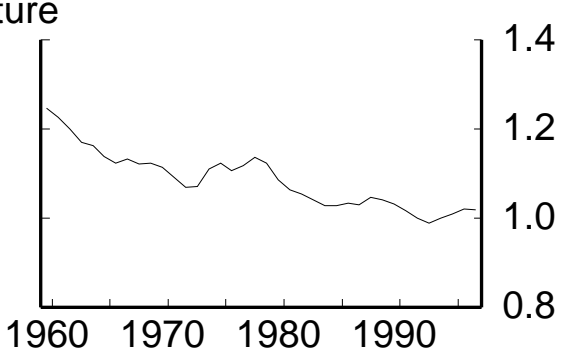

Tractors

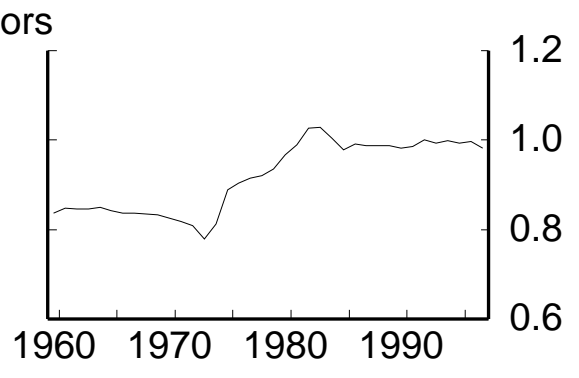

Mining Machinery

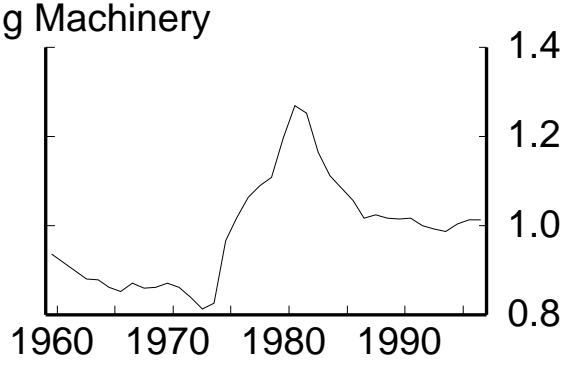

General Industrial

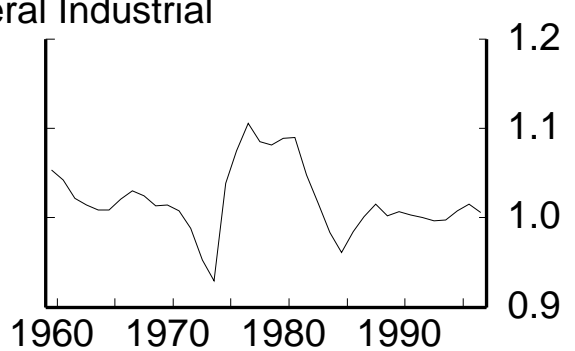

Fabricated Metals

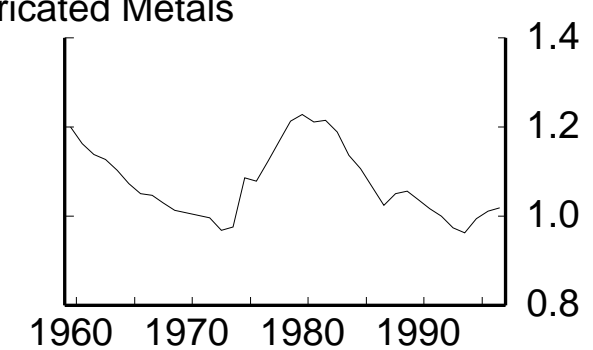

Agricultural Machinery

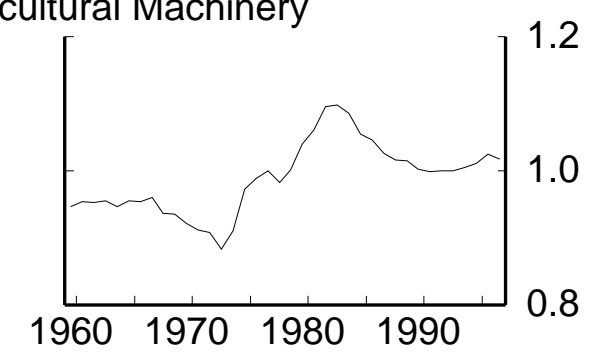

Metalworking Machinery

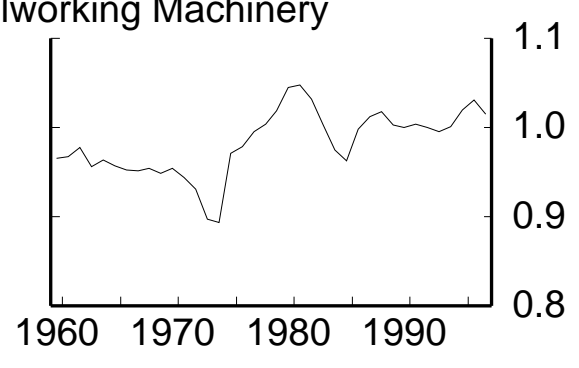

Office and Computing

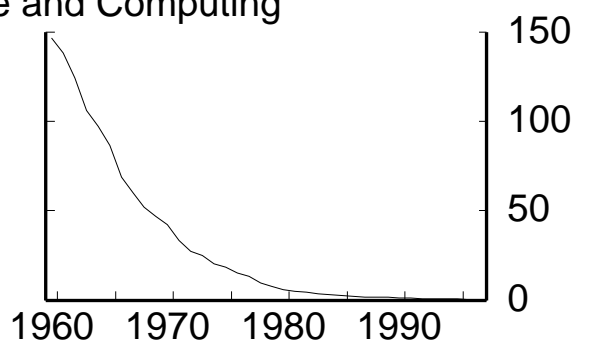

Engines and Turbines

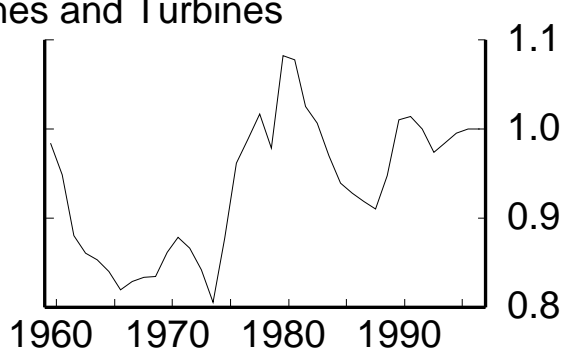

Construction Machinery

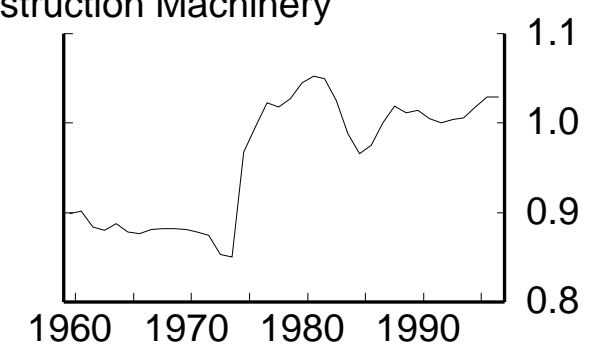

Special Industrial

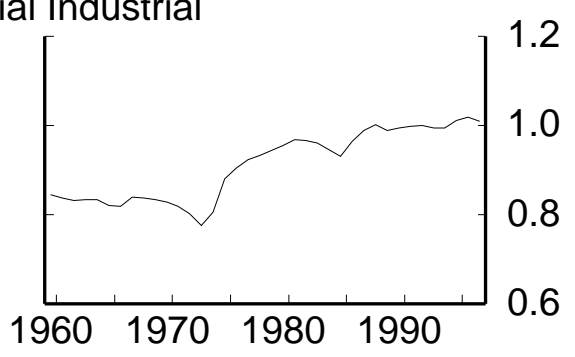

Service Industry Machinery

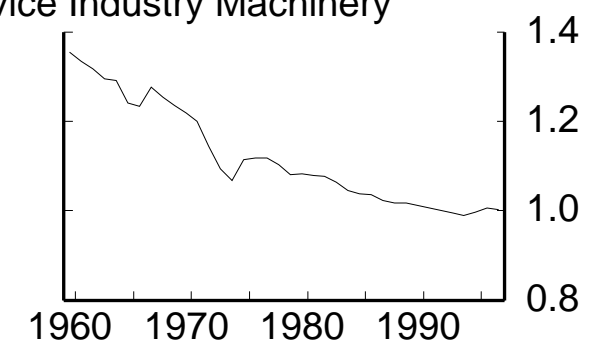


Figure 1B

Equipment Prices Relative to the GDP Deflator

Indexes (1992=1)

Electrical Transmission

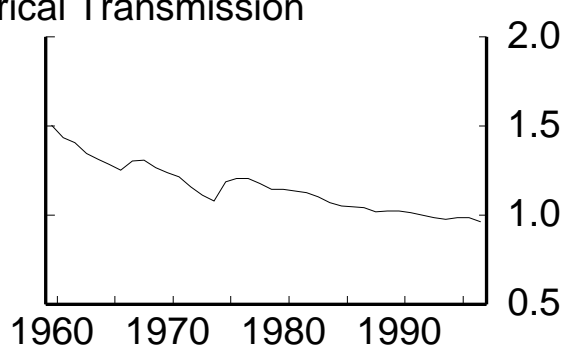

$\infty$

Trucks

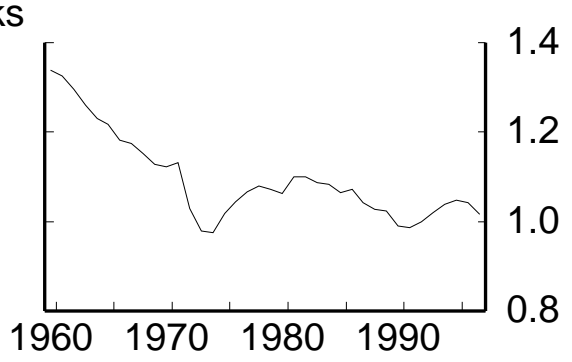

Ships and Boats

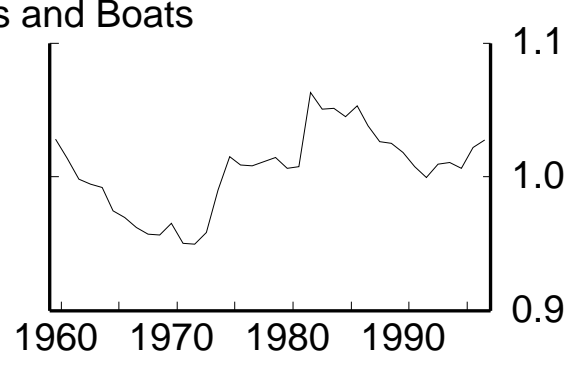

Other Equipment

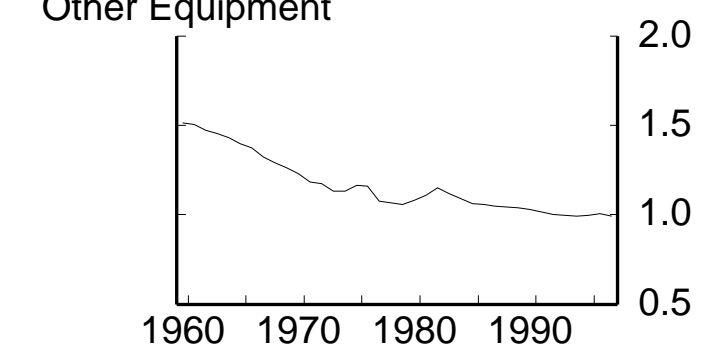

Communications

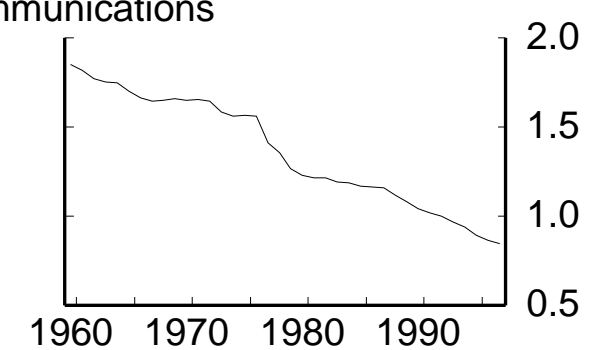

Autos

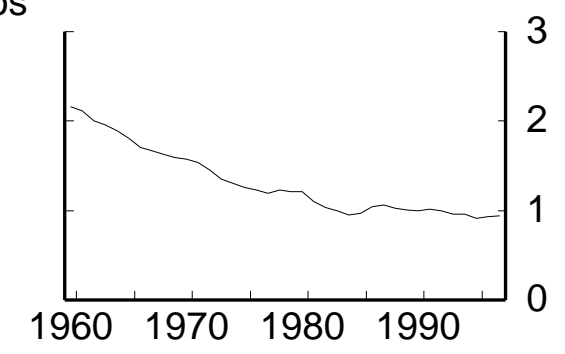

Railroad Equipment

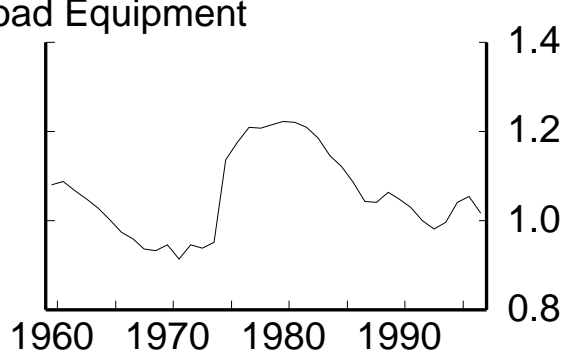

Electrical Machinery

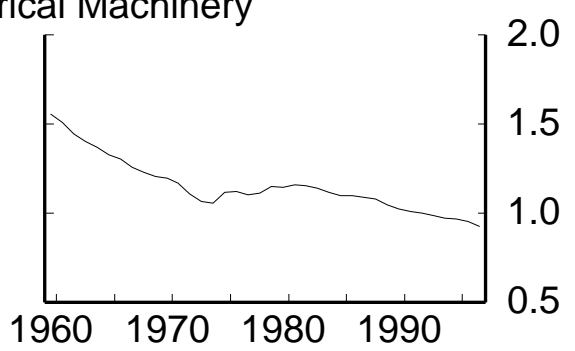

Aircraft

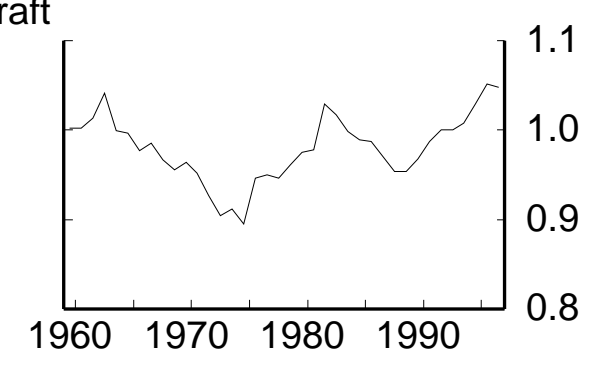

Instruments

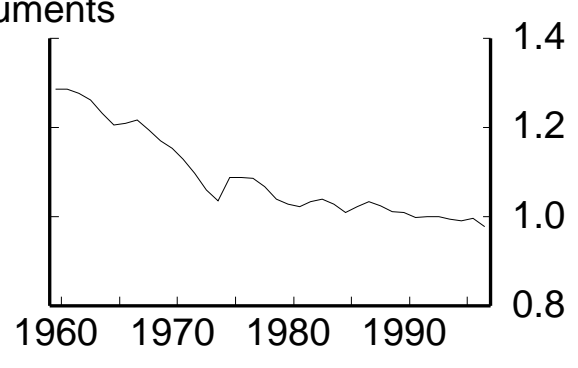


Figure 2A

Detrended Relative Equipment Prices and the ITC

Dashed Line is the ITC (Scale on Left Axis)
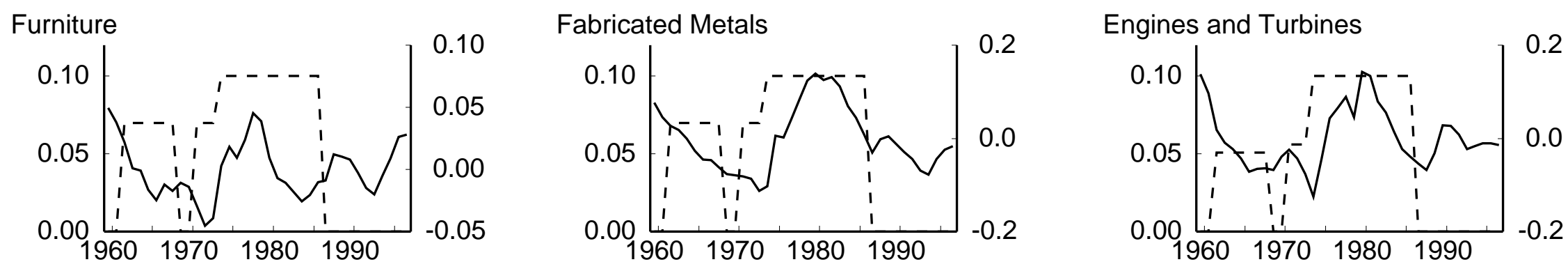

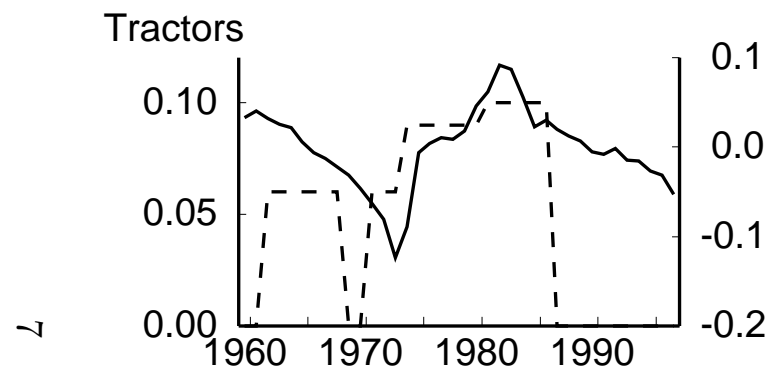

Agricultural Machinery

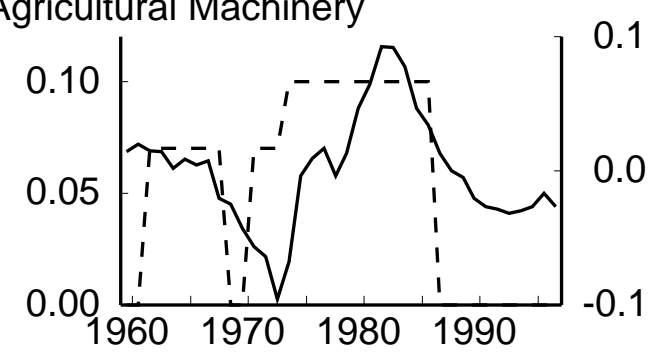

Metalworking Machinery

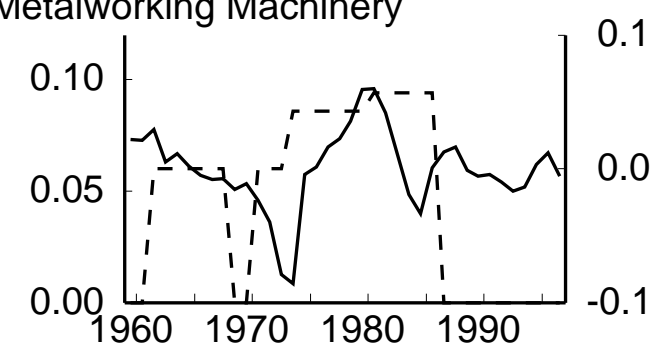

Office and Computing

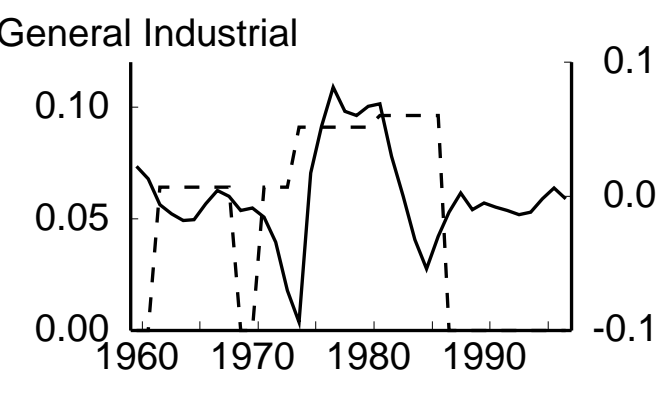

Mining Machinery

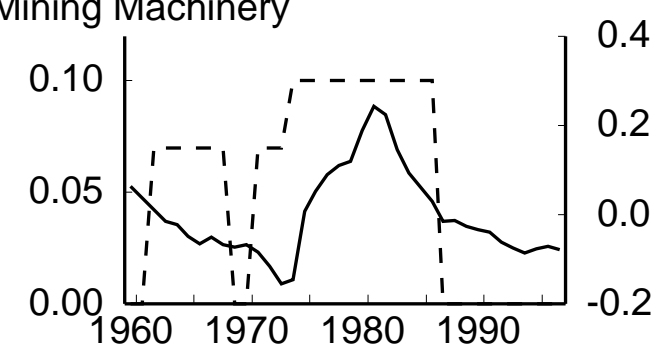

General Industrial

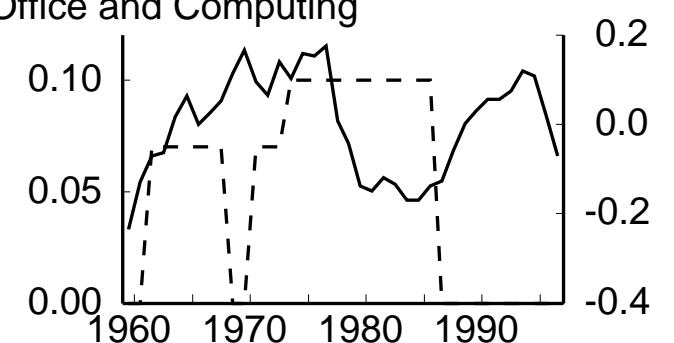

Construction Machinery

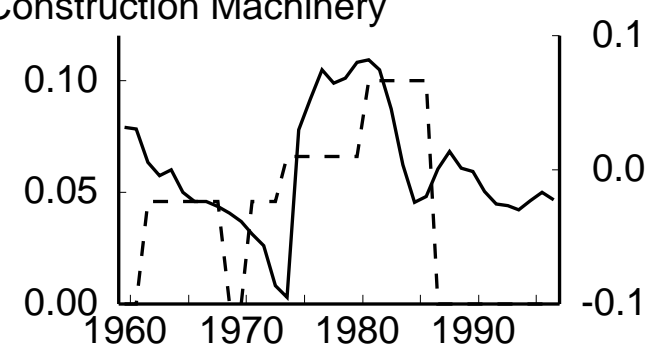

Special Industrial

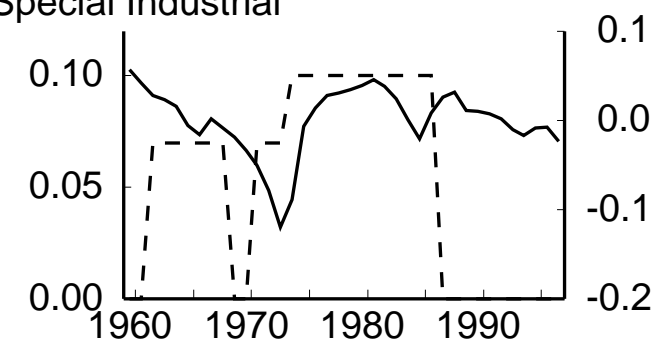

Service Industry Machinery

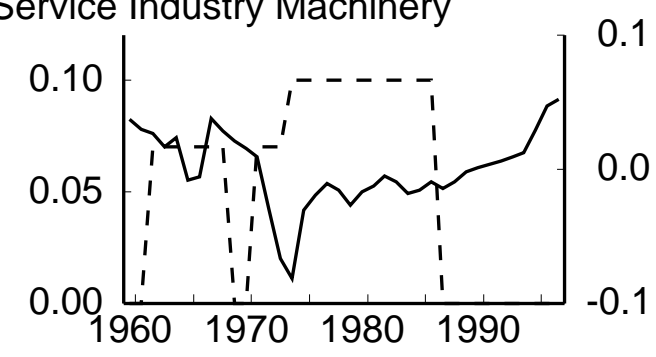


Figure 2B

Detrended Relative Equipment Prices and the ITC

Dashed Line is the ITC (Scale on Left Axis)
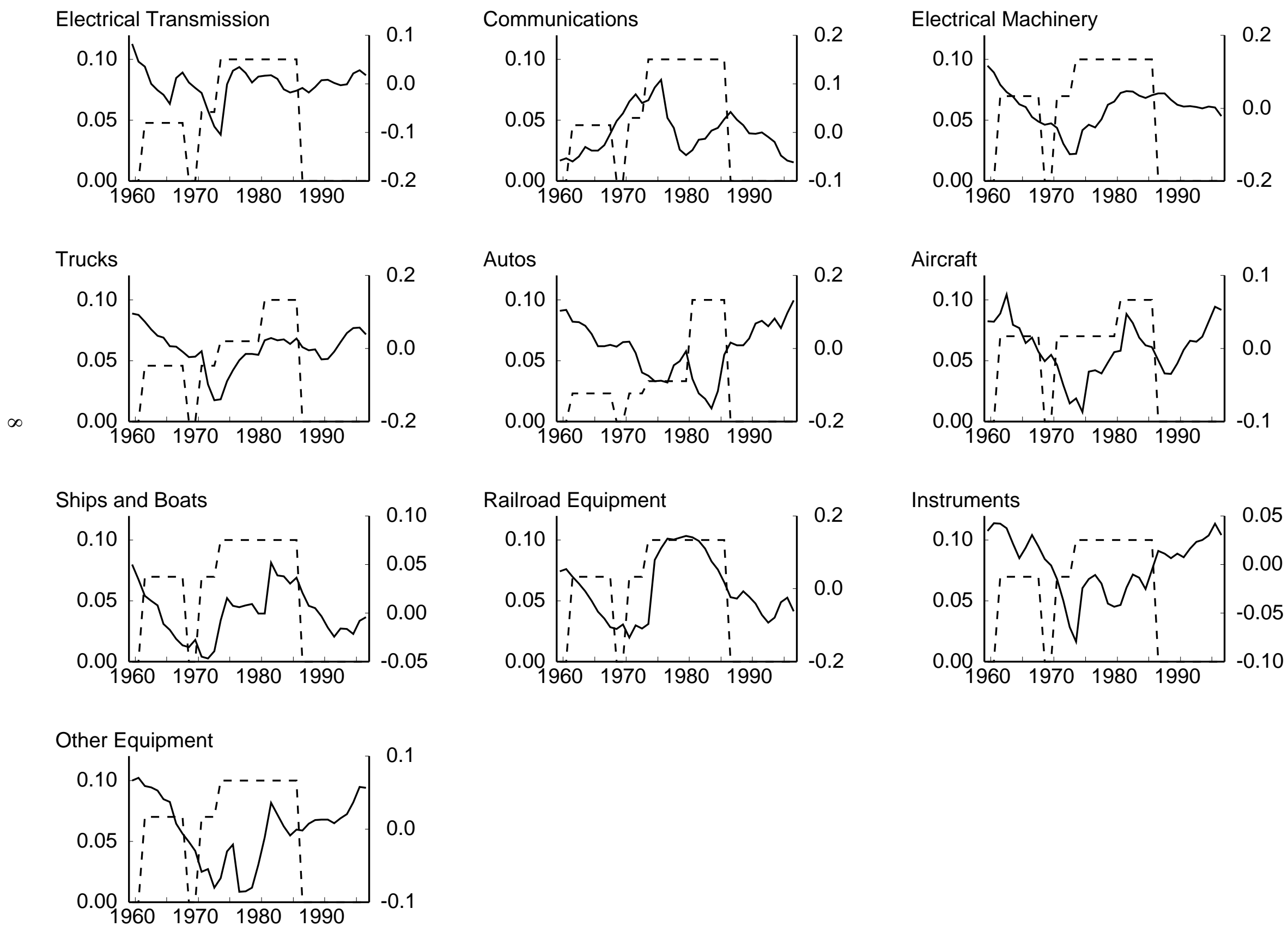
briefly discontinued during the late 1960s, re-introduced in 1971, strengthened in 1974, and then strengthened again for a small number of equipment types in the early 1980s. The ITC was abolished in 1986 and has not been re-introduced since, although it did form part of the failed 1993 Clinton stimulus plan.

That there is a positive correlation between the ITC and the detrended relative price for many types of equipment is apparent from Figures $2 \mathrm{~A}$ and $2 \mathrm{~B}$; a number of the equipment prices have correlations higher than 0.4 although the average correlation with the ITC across the 22 equipment types is only 0.09 . It is also clear that, for most equipment types, the positive correlation is driven by the hump-shaped pattern for relative prices since the mid-1970s. Relative prices for equipment were high during the mid-1970s and early 1980s when the credit was at its most generous; they were low during the late 1980s and 1990s after the repeal of the ITC. However, the year-to-year movements in equipment prices and the ITC are usually not closely related. In particular, detrended relative equipment prices fell throughout the 1960s despite the introduction of the ITC and the timing of the 1980s decline in relative prices does not line up well with the 1986 repeal of the ITC.

\subsection{Equipment Prices and Intermediate Input Prices}

The relationship between the ITC and equipment prices suggests the possibility that the swings in these prices have been due to shifts in the demand for equipment caused by changes in tax incentives. An alternative possibility is that these swings were due to supply shocks. Indeed, the 1974-75 surge in equipment prices lines up exactly with the initial OPEC energy price increases. The 1975 Economic Report of the President (pg. 39) noted the rapid growth in equipment prices and explained it as being due to rising costs. As can be seen in Figure 3, during this period, firms had to deal with more than just a surge in energy prices. The abolition of price controls in 1974 and a worldwide jump in commodity prices also contributed to rising materials costs. The PPI for intermediate materials rose an average of 11.2 percent per year over the period 1974-81, compared with an average rise of 8.1 percent for the GDP deflator. ${ }^{3}$ This likely contributed to equipment prices rising faster than GDP prices, since the bundle of goods and services making up GDP contains a number of large categories, most notably personal consumption expenditures on non-energy

\footnotetext{
${ }^{3}$ See Bruno (1984) for a discussion of the rise in materials prices during this period and its potential relationship with the productivity slowdown.
} 
Figure 3

PPIs for Energy and Materials Relative to the GDP Deflator, Indexes (1992 =1)
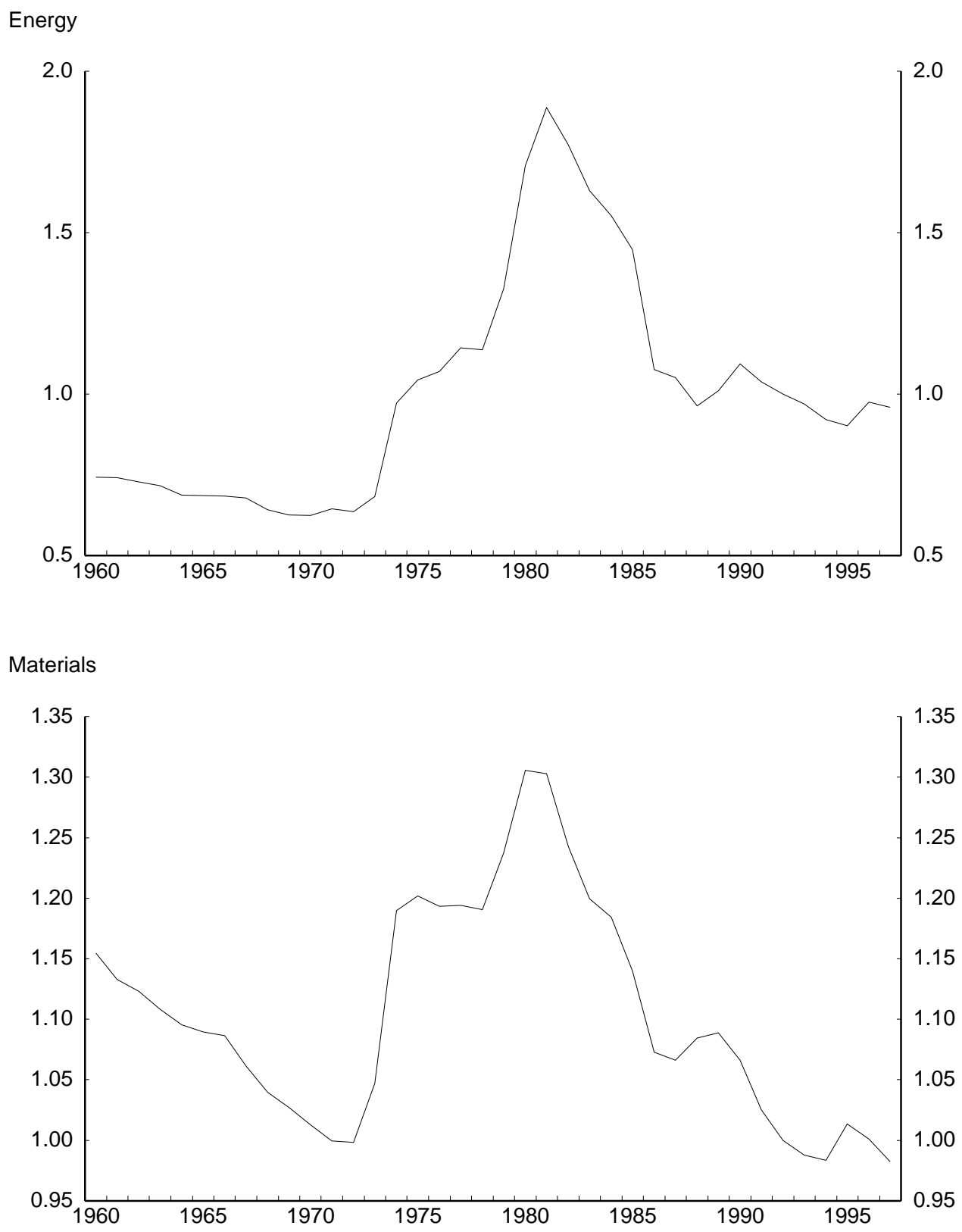
Figure 4A

Detrended Relative Prices for Equipment and Intermediate Inputs

Dashed Line is the Detrended Relative Price for Intermediate Inputs (Scale on Left Axis)
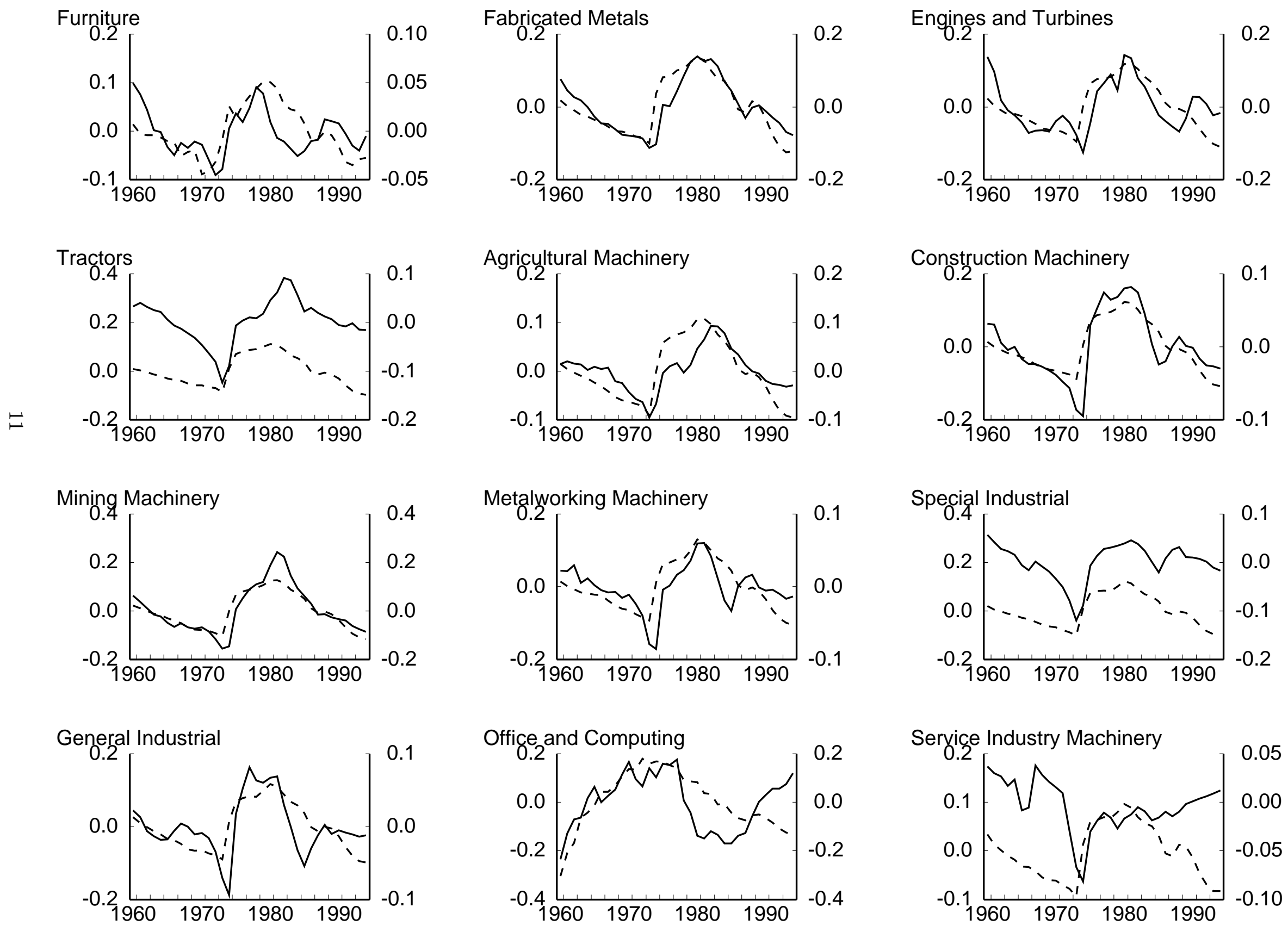


\section{Figure 4B}

\section{Detrended Relative Prices for Equipment and Intermediate Inputs}

Dashed Line is the Detrended Relative Price for Intermediate Inputs (Scale on Left Axis)
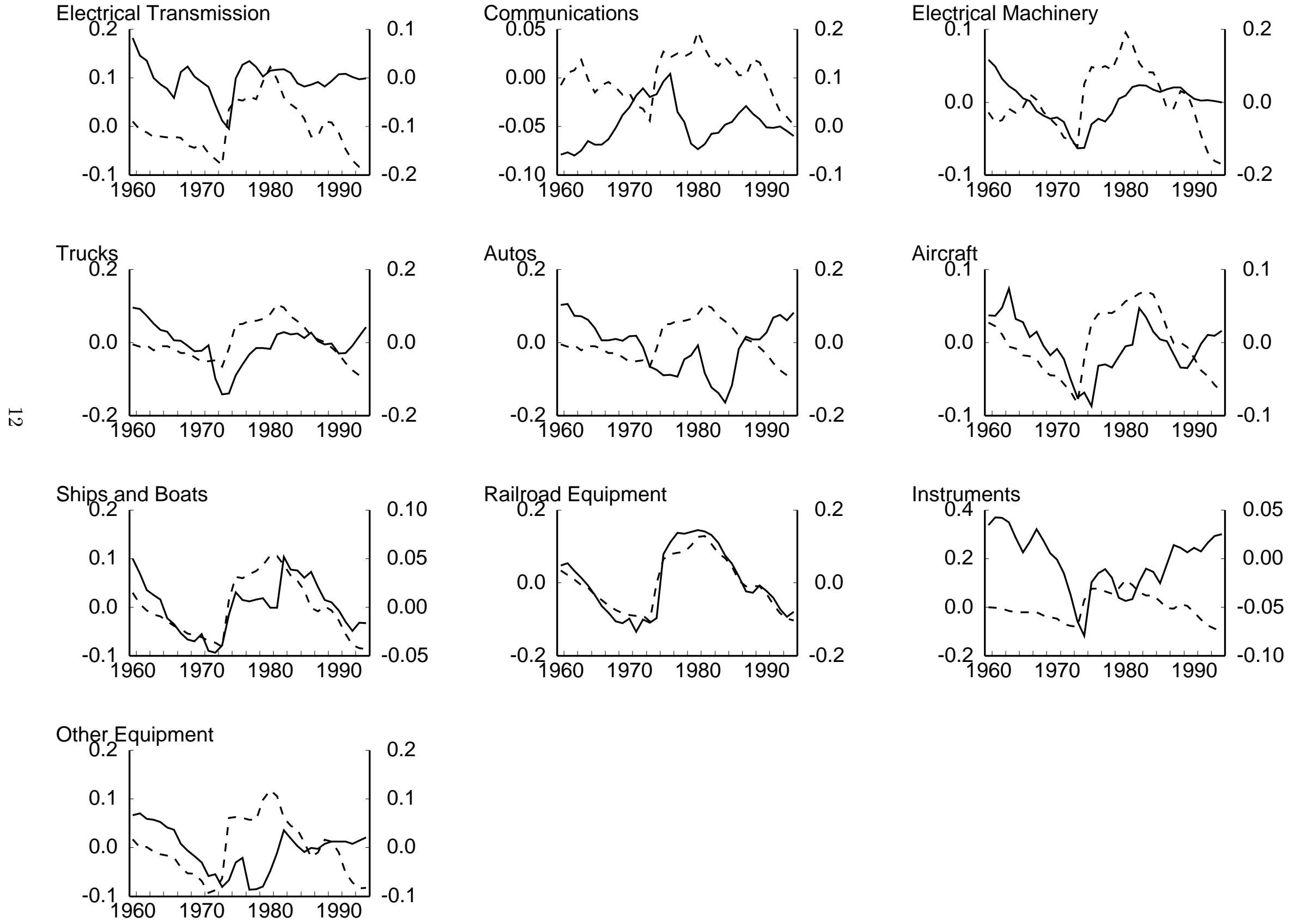
services, which require very little raw materials. ${ }^{4}$

To assess the importance of movements in input costs, I used price deflators for intermediate inputs from the NBER manufacturing productivity database (Bartelsman and Gray, 1996). These price deflators, available for all 4-digit manufacturing industries from 1958 to 1994, were calculated using Input-Output tables and price deflators for 529 types of material inputs and 6 types of energy inputs. By matching each type of equipment with the two, three, or four-digit industry that produces it, I derived price deflators for the intermediate inputs required to produce each type of equipment. ${ }^{5}$ Figures $4 \mathrm{~A}$ and $4 \mathrm{~B}$ show the detrended relative equipment prices as the solid lines and the detrended relative price of intermediate inputs as the dashed lines. ${ }^{6}$ It is fairly clear from these charts that the input price deflators match up closer with the behavior of equipment prices than the ITCs. The average correlation of 0.42 is far higher and 12 of the 22 equipment prices have correlations higher than 0.54 , which is the highest correlation between any price and the ITC. However, while certainly suggestive, these simple summary statistics do not rule out the hypothesis that investment tax incentives also affect equipment prices, but rather suggest the need for inclusion of intermediate input costs as explanatory variables in equipment price regressions.

\section{$3 \quad$ Regressions}

The basic regression specification is

$$
\log \left(P E_{i t}\right)=\alpha_{i}+\beta_{i}\left(T A X_{i t}\right)+\gamma_{i} \log \left(P M_{i t}\right)+\theta_{i} t+\gamma_{i} G R O W_{t}+\delta_{i} N I X O N_{t}+\epsilon_{i t}
$$

where $P E_{i t}$ is the relative price of equipment of type $i$ (where relative means in relation to the GDP deflator), $P M_{i t}$ is the relative price of intermediate inputs for equipment of type $i, t$ is a time trend, GROW is GDP growth, NIXON is a variable accounting for the Nixon price controls from 1971-74, and $T A X_{i t}$ is a variable measuring investment tax incentives. This differs from Goolsbee's specification only in including $P M$ and omitting exchange rate variables, which I did not find had a significant effect or influenced the results.

\footnotetext{
${ }^{4}$ In 1974 non-energy services accounted for 25 percent of GDP, and the price deflator for this category fell substantially relative to the GDP deflator.

${ }^{5}$ The details of this matching exercise are provided in Appendix A.

${ }^{6}$ It was necessary to detrend the relative intermediate input prices since for some industries, such as computing, material prices have fallen rapidly over time.
} 
All equations were estimated using the Seemingly Unrelated Regression technique and the estimation sample was 1961-1994.

\subsection{Static Regression Results}

Table 1 reports the results from estimation of equation 6 both with and without intermediate input prices, using the ITC as the $T A X_{i t}$ variable. While Goolsbee's reported results used an $\mathrm{AR}(2)$ correction, the results reported here without any correction for autocorrelation are very similar, both in terms of which categories appear to respond strongly to tax incentives and in terms of the magnitude of the coefficients: Restricting the effect of the ITC to be the same across all equipment types gives a coefficient of 0.30 (standard error, 0.02) compared with Goolsbee's estimate of 0.39 (standard error, 0.03). However, once $P M$ is added as an explanatory variable, this apparently strong relationship does not hold up. Most of the significant coefficients on the ITC disappear, 14 of the 22 coefficients on the ITC are negative, and the pooled coefficient is significantly negative. Conversely, there is consistent evidence for a significant positive effect for $P M$. Moreover, the addition of $P M$ improves the fit of most of the regressions, most notably those that had previously suggested a strong relationship between equipment prices and the ITC.

Of course, the ITC summarizes only one aspect of the effects of the tax code on the incentive to purchase capital equipment. A broader measure also used by Goolsbee is the well-known Hall-Jorgenson tax term that features in the user cost of capital formula. This term is defined as $\frac{1-I T C-\tau z}{1-\tau}$, where $\tau$ is the marginal corporate income tax rate and $z$ is the present discounted value of depreciation allowances per dollar invested. Table 2 repeats the regressions using this full tax term in place of the ITC and shows similar results. ${ }^{7} \mathrm{~A}$ significant relationship, although negative this time, between the tax term and the price of equipment is evident in the simple regressions, with an estimated pooled elasticity of -0.11 (standard error, 0.006), which compares with Goolsbee's estimate of -0.1774 (standard error 0.02). However, again, once we include $P M$ as an explanatory variable, these results are overturned.

\footnotetext{
${ }^{7}$ The details behind the construction of this tax term are in Appendix B. My empirical calculation differed slightly from the formula in the text in taking into account the fact that, for some years, firms were required to reduce their depreciation base by some proportion of their investment tax credit.
} 


\subsection{Dynamic Regression Results}

Tables 1 and 2 show that these basic regressions have highly autocorrelated errors (although those including $P M$ tend to have higher Durbin-Watson statistics). This suggests that the simple specification is missing some important dynamics. Goolsbee's solution to this problem, an $\mathrm{AR}(2)$ correction, implies a very specific form of dynamic specification in which both lagged dependent and explanatory variables affect the current period's value of the dependent variable. However, simple tests suggested that including lags of the explanatory variables did not improve the residual autocorrelation problem but that including two lags of the dependent variable did. Thus, Tables 3 and 4 repeat the regressions from Tables 1 and 2, this time with two lags of the dependent variable. The tables report the long-run effects for the tax and input price variables; in other words, they report the estimated coefficients divided by one minus the sum of the coefficients on the lagged dependent variables. Standard errors for these long-run effects were calculated by the Delta method.

The message from the results in Tables 3 and 4 is very similar to the earlier results. Without $P M$, there appears to be a strong relationship between the prices for a large number of equipment types and the ITC or tax term; once $P M$ is included these coefficients usually become insignificant. One exception is the "pooled estimate" for the tax term elasticity which is -0.09 (standard error 0.03). However, this estimate is something of an anomaly since none of the individual regression coefficients for this term are significantly negative.

One question concerning these results relates to the econometric specification. Kevin Hassett and Glenn Hubbard (1998) have critiqued Goolsbee's results as being the result of a spurious regression, arguing that the relative equipment prices and tax term variables are both I(1) variables but are not cointegrated. In this case, the regression should be run in differences and they show that when this is done, they do not obtain significant coefficients on the tax variables. That the tax variables are insignificant once the regression is estimated in differences should not be too surprising since Figures $2 \mathrm{~A}$ and $2 \mathrm{~B}$ show that while some of the relative equipment prices are correlated with the level of the ITC, the year-to-year movements tend not to be closely related. Conversely, I find that if one estimates the SUR equation system in first-differences including $P M$ then one still obtains highly significant coefficients on $P M$, similar in size to those obtained from the levels estimation. Thus whether the regression should be run in levels or differences does not affect our conclusion. 
Given that econometric tests are notoriously poor at distinguishing unit root behavior from trend stationarity (which may describe relative equipment prices well) or stationarity with regime shifts (which may fit the corporate tax code well) it is also very possible that the levels estimates reported here are the appropriate ones.

\subsection{Interpretation}

These results suggest that regressions relating equipment prices to investment tax incentives but excluding input prices are mis-specified. The correlation between the tax variables and input prices produces spurious estimates of a large effect of tax incentives on equipment prices, estimates that disappear once one controls for input prices.

It is important to note that despite the coincidence of the common pattern displayed by most of the equipment prices with shifts in the price of oil, these results are not obtained because of an omitted aggregate variable that could be captured using year dummies. Indeed, Goolsbee reports regressions including year dummies designed to pick up aggregate effects and finds that the inclusion of these dummies does not affect his estimates. This result is still qualitatively true with this updated data set. While I found that the inclusion of year dummies produces a weaker estimated relationship between tax variables and equipment prices, many of the tax coefficients are still significant. However, again, once $P M$ is included these results disappear and the fit of the equations is noticeably improved. That equipment-specific input prices explain the behavior of equipment prices better than aggregate year dummies should not be surprising given the facts documented in Section 2. The magnitudes of the swings in relative equipment prices and in input costs differed markedly across different types of equipment. Thus, one would not expect that aggregate year-dummies would capture these effects as well as the inclusion of the appropriate equipment-specific input price variable.

Do these results imply that investment demand is unaffected by tax incentives? Not necessarily. As discussed above, there were two cases in which tax incentives had no effect on equipment prices. The first was one in which the equipment supply curve was upwardsloping and firms had price-insensitive investment demand $(\beta=0)$. The other was the case

in which free entry led to a flat supply curve, no matter what value $\beta$ took. Note, though, that the equipment price elasticity with respect to $P M$ differed in these two cases: With an upward-sloping supply curve, the elasticity should equal the ratio of intermediate input 
Table 1: Equipment Prices, Material Prices, and the ITC

\begin{tabular}{|l|l|l|l|l|l|l|l|}
\hline & \multicolumn{2}{|c|}{ No Input Prices } & \multicolumn{4}{|c|}{ Including Input Prices } \\
\hline Asset Class & ITC & DW & $\bar{R}^{2}$ & ITC & $P M$ & DW & $R^{2}$ \\
\hline 1. Furniture & $0.11(.06)$ & 0.39 & .51 & $-0.25(.05)$ & $0.44(.03)$ & 1.07 & .83 \\
\hline 2. Fabricated Metals & $1.02(.12)$ & 0.61 & .57 & $0.16(.09)$ & $0.76(.04)$ & 0.72 & .78 \\
\hline 3. Engines & $0.50(.13)$ & 0.69 & .73 & $-0.62(.18)$ & $1.05(.11)$ & 0.88 & .83 \\
\hline 4. Tractors & $0.49(.08)$ & 0.71 & .93 & $0.13(.09)$ & $0.37(.04)$ & 0.61 & .95 \\
\hline 5. Agric. Machinery & $0.65(.09)$ & 0.79 & .87 & $0.29(.09)$ & $0.37(.05)$ & 0.62 & .91 \\
\hline 6. Constr. Machinery & $0.56(.08)$ & 0.71 & .86 & $-0.43(.03)$ & $0.78(.03)$ & 1.38 & .96 \\
\hline 7. Mining Machinery & $1.43(.16)$ & 0.73 & .79 & $0.07(.11)$ & $1.18(.07)$ & 0.77 & .92 \\
\hline 8. Metalworking Mach. & $0.21(.06)$ & 0.75 & .83 & $-0.30(.05)$ & $0.45(.04)$ & 1.16 & .91 \\
\hline 9. Special Ind. Mach. & $0.17(.05)$ & 0.71 & .95 & $-0.27(.05)$ & $0.45(.03)$ & 1.08 & .98 \\
\hline 10. General Ind. Mach. & $0.27(.09)$ & 0.66 & .51 & $-0.35(.08)$ & $0.63(.05)$ & 0.91 & .72 \\
\hline 11. Office \& Computers & $-0.72(.32)$ & 0.39 & .99 & $-1.61(.28)$ & $0.81(.05)$ & 0.75 & .99 \\
\hline 12. Service Ind. Mach. & $-0.15(.05)$ & 1.21 & .94 & $-0.05(.06)$ & $-0.09(.04)$ & 1.21 & .94 \\
\hline 13. Electrical Distrib. & $0.07(.06)$ & 1.10 & .90 & $-0.09(.07)$ & $0.27(.05)$ & 1.32 & .91 \\
\hline 14. Communications & $0.20(.10)$ & 0.51 & .96 & $0.12(.11)$ & $0.29(.16)$ & 0.55 & .96 \\
\hline 15. Oth. Electr. Equip. & $0.03(.11)$ & 0.34 & .76 & $-0.06(.12)$ & $0.16(.07)$ & 0.35 & .77 \\
\hline 16. Trucks and Buses & $-0.03(.11)$ & 0.46 & .64 & $0.10(.12)$ & $-0.11(.08)$ & 0.46 & .64 \\
\hline 17. Autos & $-2.33(.17)$ & 0.95 & .97 & $-1.42(.15)$ & $-0.51(.08)$ & 0.82 & .97 \\
\hline 18. Aircraft & $0.12(.09)$ & 0.70 & .68 & $0.17(.09)$ & $-0.07(.08)$ & 0.71 & .68 \\
\hline 19. Ships & $0.39(.08)$ & 0.59 & .88 & $0.11(.08)$ & $0.30(.04)$ & 0.64 & .92 \\
\hline 20. Railroad Equipment & $1.38(.15)$ & 0.77 & .68 & $-0.16(.09)$ & $1.37(.04)$ & 1.92 & .96 \\
\hline 21. Instruments & $-0.29(.04)$ & 1.52 & .94 & $-0.18(.05)$ & $-0.10(.03)$ & 1.51 & .94 \\
\hline 22. Other Equipment & $-0.20(.12)$ & 0.49 & .87 & $-0.11(.13)$ & $-0.09(.06)$ & 0.49 & .87 \\
\hline POOLED & $0.30(.02)$ & & & $-0.25(.02)$ & $0.55(.01)$ & & \\
\hline
\end{tabular}

Sample is 1961-1994. Standard errors in parentheses. The dependent variable is the log of the equipment price minus the log of the GDP deflator. $P M$ is the log of the relative equipment-specific price of energy and material inputs. Each equation also includes a time trend, GDP growth, and a Nixon price controls variable and the 22 equations were estimated jointly using SUR. The pooled coefficients were restricted to be the same across all equations. 
Table 2: Equipment Prices, Material Prices, and the Hall-Jorgenson Tax Term

\begin{tabular}{|l|l|l|l|l|l|l|l|}
\hline & \multicolumn{3}{|c|}{ No Input Prices } & \multicolumn{3}{|c|}{ Including Input Prices } \\
\hline Asset Class & Tax Term & DW & $R^{2}$ & Tax Term & $P M$ & DW & $R^{2}$ \\
\hline 1. Furniture & $-0.13(.02)$ & 0.58 & .56 & $0.01(.02)$ & $0.33(.03)$ & 0.54 & .77 \\
\hline 2. Fabricated Metals & $-0.40(.05)$ & 0.42 & .42 & $0.08(.04)$ & $0.84(.04)$ & 0.75 & .79 \\
\hline 3. Engines & $-0.25(.07)$ & 0.64 & .69 & $0.31(.07)$ & $0.95(.09)$ & 0.81 & .83 \\
\hline 4. Tractors & $-0.03(.03)$ & 0.38 & .90 & $0.21(.03)$ & $0.57(.03)$ & 1.00 & .97 \\
\hline 5. Agric. Machinery & $-0.08(.03)$ & 0.32 & .78 & $0.15(.03)$ & $0.64(.04)$ & 0.77 & .93 \\
\hline 6. Constr. Machinery & $-0.20(.02)$ & 0.58 & .83 & $0.06(.02)$ & $0.66(.03)$ & 1.16 & .96 \\
\hline 7. Mining Machinery & $-0.28(.06)$ & 0.30 & .63 & $0.31(.03)$ & $1.37(.05)$ & 0.95 & .94 \\
\hline 8. Metalworking Mach. & $-0.11(.02)$ & 0.72 & .81 & $0.09(.02)$ & $0.39(.04)$ & 1.03 & .90 \\
\hline 9. Special Ind. Mach. & $-0.10(.02)$ & 0.69 & .94 & $0.10(.02)$ & $0.40(.03)$ & 1.03 & .98 \\
\hline 10. General Ind. Mach. & $-0.23(.03)$ & 0.78 & .52 & $-0.02(.03)$ & $0.47(.05)$ & 0.85 & .69 \\
\hline 11. Office \& Computers & $-0.15(.10)$ & 0.37 & .99 & $0.23(.15)$ & $0.55(.08)$ & 0.32 & .99 \\
\hline 12. Service Ind. Mach. & $0.10(.02)$ & 1.34 & .95 & $0.07(.02)$ & $-0.06(.04)$ & 1.34 & .95 \\
\hline 13. Electrical Distrib. & $0.00(.03)$ & 1.04 & .90 & $0.08(.04)$ & $0.29(.05)$ & 1.38 & .92 \\
\hline 14. Communications & $-0.15(.07)$ & 0.52 & .96 & $-0.11(.08)$ & $0.34(.18)$ & 0.58 & .96 \\
\hline 15. Oth. Electr. Equip. & $0.11(.03)$ & 0.34 & .78 & $0.26(.04)$ & $0.39(.06)$ & 0.50 & .81 \\
\hline 16. Trucks and Buses & $0.34(.03)$ & 0.70 & .76 & $0.36(.03)$ & $-0.09(.06)$ & 0.74 & .77 \\
\hline 17. Autos & $-0.20(.05)$ & 0.25 & .92 & $-0.04(.03)$ & $-0.90(.08)$ & 0.63 & .96 \\
\hline 18. Aircraft & $0.06(.04)$ & 0.74 & .67 & $0.10(.04)$ & $0.09(.07)$ & 0.80 & .67 \\
\hline 19. Ships & $-0.15(.03)$ & 0.42 & .85 & $0.01(.03)$ & $0.33(.04)$ & 0.64 & .92 \\
\hline 20. Railroad Equipment & $-0.65(.06)$ & 0.57 & .56 & $0.08(.04)$ & $1.37(.04)$ & 1.90 & .96 \\
\hline 21. Instruments & $0.11(.02)$ & 1.26 & .92 & $0.06(.02)$ & $-0.15(.03)$ & 1.46 & .94 \\
\hline 22. Other Equipment & $0.18(.04)$ & 0.58 & .89 & $0.24(.05)$ & $0.04(.04)$ & 0.64 & .89 \\
\hline POOLED & $-0.11(.006)$ & & & $0.09(.005)$ & $0.48(.01)$ & & \\
\hline
\end{tabular}

Sample is 1961-1994. Standard errors in parentheses. The dependent variable is the log of the equipment price minus the log of the GDP deflator. $P M$ is the log of the relative equipment-specific price of energy and material inputs. Each equation also includes a time trend, GDP growth, and a Nixon price controls variable and the 22 equations were estimated jointly using SUR. The pooled coefficients were restricted to be the same across all equations. 
Table 3: Estimated Long-Run Effects of the ITC

\begin{tabular}{|l|l|l|l|l|l|}
\hline & \multicolumn{2}{|c|}{ No Input Prices } & \multicolumn{3}{|c|}{ Including Input Prices } \\
\hline Asset Class & ITC & $\rho$ & ITC & $P M$ & $\rho$ \\
\hline 1. Furniture & $0.20(0.12)$ & $.62(.05)$ & $-0.25(0.07)$ & $0.42(0.05)$ & $.40(.05)$ \\
\hline 2. Fabricated Metals & $1.46(0.34)$ & $.74(.04)$ & $-0.04(0.20)$ & $1.09(0.12)$ & $.62(.03)$ \\
\hline 3. Engines & $0.64(0.29)$ & $.58(.06)$ & $-0.49(0.37)$ & $0.97(0.25)$ & $.54(.04)$ \\
\hline 4. Tractors & $0.93(0.19)$ & $.73(.03)$ & $0.11(0.21)$ & $0.69(0.14)$ & $.68(.03)$ \\
\hline 5. Agric. Machinery & $1.18(0.24)$ & $.75(.04)$ & $0.23(0.19)$ & $0.72(0.12)$ & $.65(.04)$ \\
\hline 6. Constr. Machinery & $0.66(0.20)$ & $.63(.04)$ & $-0.33(0.13)$ & $0.72(0.07)$ & $.44(.04)$ \\
\hline 7. Mining Machinery & $1.97(0.39)$ & $.75(.03)$ & $0.05(0.27)$ & $1.35(0.15)$ & $.60(.03)$ \\
\hline 8. Metalworking Mach. & $0.39(0.16)$ & $.62(.04)$ & $-0.11(0.16)$ & $0.38(0.09)$ & $.52(.05)$ \\
\hline 9. Special Ind. Mach. & $0.46(0.13)$ & $.64(.03)$ & $-0.05(0.12)$ & $0.39(0.08)$ & $.54(.03)$ \\
\hline 10. General Ind. Mach. & $0.40(0.16)$ & $.58(.04)$ & $0.14(0.17)$ & $0.28(0.10)$ & $.46(.03)$ \\
\hline 11. Office \& Computers & $-2.89(1.16)$ & $.79(.05)$ & $-3.07(1.17)$ & $0.39(0.36)$ & $.77(.08)$ \\
\hline 12. Service Ind. Mach. & $-0.05(0.09)$ & $.56(.06)$ & $0.01(0.12)$ & $-0.03(0.09)$ & $.56(.06)$ \\
\hline 13. Electrical Distrib. & $0.19(0.10)$ & $.45(.05)$ & $0.02(0.13)$ & $0.22(0.10)$ & $.45(.04)$ \\
\hline 14. Communications & $0.54(0.61)$ & $.89(.06)$ & $1.19(0.89)$ & $-2.00(1.69)$ & $.89(.06)$ \\
\hline 15. Oth. Electr. Equip. & $0.92(0.40)$ & $.85(.03)$ & $0.49(0.41)$ & $0.60(0.37)$ & $.84(.03)$ \\
\hline 16. Trucks and Buses & $0.52(0.26)$ & $.73(.05)$ & $1.05(0.44)$ & $-0.36(0.28)$ & $.75(.04)$ \\
\hline 17. Autos & $-2.17(0.48)$ & $.61(.06)$ & $-0.10(0.48)$ & $-0.85(0.21)$ & $.56(.04)$ \\
\hline 18. Aircraft & $0.37(0.20)$ & $.63(.07)$ & $0.31(0.33)$ & $0.15(0.30)$ & $.69(.08)$ \\
\hline 19. Ships & $1.14(0.29)$ & $.80(.04)$ & $0.22(0.17)$ & $0.47(0.12)$ & $.65(.06)$ \\
\hline 20. Railroad Equipment & $1.48(0.47)$ & $.77(.04)$ & $-0.21(0.14)$ & $1.35(0.07)$ & $.33(.04)$ \\
\hline 21. Instruments & $-0.27(0.07)$ & $.42(.07)$ & $-0.16(0.08)$ & $-0.09(0.06)$ & $.41(.06)$ \\
\hline 22. Other Equipment & $0.35(0.56)$ & $.85(.06)$ & $-1.51(3.02)$ & $4.31(7.26)$ & $.96(.06)$ \\
\hline POOLED & $0.49(0.09)$ & $.76(.06)$ & $-0.02(0.05)$ & $0.49(0.08)$ & $.71(.04)$ \\
\hline
\end{tabular}

Sample is 1961-1994. Standard errors in parentheses. The dependent variable is the log of the equipment price minus the log of the GDP deflator. $P M$ is the log of the relative equipment-specific price of energy and material inputs. Each equation also includes two lags of the relative equipment price, a time trend, GDP growth, and a Nixon price controls variable and the 22 equations were estimated jointly using SUR. The pooled coefficients were restricted to be the same across all equations. Note: $\rho$ is the sum of the coefficients on lagged relative equipment prices. 
Table 4: Estimated Long-Run Effects of the Hall-Jorgenson Tax Term

\begin{tabular}{|l|l|l|l|l|l|}
\hline & \multicolumn{2}{|c|}{ No Input Prices } & \multicolumn{3}{c|}{ Including Input Prices } \\
\hline Asset Class & Tax Term & $\rho$ & Tax Term & $P M$ & $\rho$ \\
\hline 1. Furniture & $-0.17(0.07)$ & $.65(.05)$ & $0.02(0.04)$ & $0.32(0.05)$ & $.45(.05)$ \\
\hline 2. Fabricated Metals & $-0.97(0.24)$ & $.79(.04)$ & $-0.09(0.09)$ & $1.03(0.10)$ & $.62(.03)$ \\
\hline 3. Engines & $-0.21(0.21)$ & $.63(.06)$ & $0.54(0.17)$ & $1.06(0.18)$ & $.55(.04)$ \\
\hline 4. Tractors & $-1.13(0.54)$ & $.90(.03)$ & $-0.02(0.09)$ & $0.80(0.11)$ & $.70(.04)$ \\
\hline 5. Agric. Machinery & $-0.75(0.31)$ & $.88(.04)$ & $0.01(0.07)$ & $0.87(0.10)$ & $.65(.04)$ \\
\hline 6. Constr. Machinery & $-0.49(0.16)$ & $.79(.03)$ & $-0.05(0.05)$ & $0.56(0.06)$ & $.49(.04)$ \\
\hline 7. Mining Machinery & $-1.44(0.45)$ & $.86(.03)$ & $0.06(0.11)$ & $1.37(0.10)$ & $.58(.03)$ \\
\hline 8. Metalworking Mach. & $-0.23(0.09)$ & $.67(.04)$ & $-0.06(0.07)$ & $0.31(0.07)$ & $.54(.05)$ \\
\hline 9. Special Ind. Mach. & $-0.38(0.10)$ & $.72(.03)$ & $-0.11(0.07)$ & $0.33(0.07)$ & $.59(.03)$ \\
\hline 10. General Ind. Mach. & $-0.26(0.08)$ & $.60(.03)$ & $0.23(0.17)$ & $0.22(0.09)$ & $.53(.04)$ \\
\hline 11. Office \& Computers & $2.50(2.45)$ & $.90(.07)$ & $2.31(2.85)$ & $-0.53(1.49)$ & $.91(.09)$ \\
\hline 12. Service Ind. Mach. & $-0.01(0.06)$ & $.62(.07)$ & $-0.01(0.06)$ & $-0.02(0.08)$ & $.58(.07)$ \\
\hline 13. Electrical Distrib. & $-0.09(0.07)$ & $.48(.05)$ & $0.03(0.07)$ & $0.29(0.09)$ & $.43(.05)$ \\
\hline 14. Communications & $0.14(0.53)$ & $.90(.03)$ & $0.47(0.84)$ & $-0.87(1.55)$ & $.92(.05)$ \\
\hline 15. Oth. Electr. Equip. & $-0.42(0.25)$ & $.87(.03)$ & $-0.20(0.20)$ & $0.77(0.33)$ & $.84(.03)$ \\
\hline 16. Trucks and Buses & $0.16(0.12)$ & $.67(.05)$ & $0.18(0.13)$ & $0.11(0.17)$ & $.68(.05)$ \\
\hline 17. Autos & $-0.57(0.22)$ & $.77(.05)$ & $-0.12(0.07)$ & $-0.87(0.14)$ & $.56(.04)$ \\
\hline 18. Aircraft & $-0.20(0.19)$ & $.72(.08)$ & $0.05(0.17)$ & $0.36(0.24)$ & $.71(.08)$ \\
\hline 19. Ships & $-0.79(0.32)$ & $.87(.05)$ & $-0.09(0.08)$ & $0.55(0.11)$ & $.67(.06)$ \\
\hline 20. Railroad Equipment & $-0.71(0.27)$ & $.80(.04)$ & $0.08(0.06)$ & $1.31(0.07)$ & $.31(.04)$ \\
\hline 21. Instruments & $0.11(0.04)$ & $.53(.06)$ & $0.05(0.04)$ & $-0.13(0.06)$ & $.43(.06)$ \\
\hline 22. Other Equipment & $0.15(0.22)$ & $.83(.07)$ & $0.66(0.43)$ & $1.41(1.04)$ & $.89(.06)$ \\
\hline POOLED & $-0.29(0.03)$ & $.78(.03)$ & $-0.09(0.03)$ & $0.44(0.07)$ & $.72(.04)$ \\
\hline
\end{tabular}

Sample is 1961-1994. Standard errors in parentheses. The dependent variable is the log of the equipment price minus the log of the GDP deflator. $P M$ is the log of the relative equipment-specific price of energy and material inputs. Each equation also includes two lags of the relative equipment price, a time trend, GDP growth, and a Nixon price controls variable and the 22 equations were estimated jointly using SUR. The pooled coefficients were restricted to be the same across all equations. Note: $\rho$ is the sum of the coefficients on lagged relative equipment prices. 
costs to total variable cost, while with the flat supply curve, the elasticity should equal the ratio of intermediate input costs to the total value of shipments. The estimated coefficients are closer to that implied by the flat supply curve. For the 22 types of equipment, the average value for the ratio of intermediate input costs to total variable cost (defined as the sum of energy, material, and labor costs) is 0.677 (standard error 0.083) while the average value for the ratio of intermediate input costs to the total value of shipments is 0.489 (standard error 0.084). This latter average value is close to the pooled estimates of the equipment price elasticity with respect to $P M$ reported in Tables 3 and 4.

Thus, the evidence favors the flat supply curve interpretation, implying a highly competitive market structure with free entry keeping economic profits low. Is this a credible conclusion? While the extreme assumptions of competition and free entry may not match the reality, the market for equipment in the U.S. is extremely open to international trade compared to other markets, and this probably helps to keep prices near the level consistent with zero economic profits.

\section{Equipment Tax Incentives and Materials Costs}

The results so far have used variations in input costs to show that the equipment producing industry is well approximated by the assumption of a flat supply curve. However, I have implicitly assumed that the shifts in the prices of the intermediate inputs used to produce equipment are true "supply shocks" which are independent of the tax treatment of equipment purchases. It is possible that this assumption is false. If equipment demand is price sensitive then an increase in investment tax incentives for good $i$ will raise demand for the materials used to produce good $i$. Thus, if the producers of this good represented a sufficiently large proportion of the demand for their material inputs and the supply curve for these inputs is upward-sloping, then such an increase in demand could significantly raise the price of their inputs. Indeed, it may still be that through this mechanism there is a significant "crowding out" of the positive demand effect of tax incentives, even if the supply curves for producers of capital equipment were flat.

Not surprisingly, given the correlations evident in the charts shown earlier, simple regressions of the same form as equation 6 but instead using $\log \left(P M_{i t}\right)$ as the dependent variable produce significant coefficients on tax incentives, which could be construed as evidence in favor of this interpretation. However, for a number of reasons, it seems far more 
likely that this relationship is spurious.

Firstly, I found that if one augments these simple input price regressions with related variables likely to be exogenous to domestic equipment demand, such as the aggregate PPIs for energy and steel (both of which are largely determined by worldwide supply and demand conditions) then tax incentives are no longer a significant explanatory variable. Secondly, information on quantity movements points against the demand-shock interpretation of input price movements. In particular, the correlation between tax incentives and input prices for equipment producers is largely driven by the common U-shaped pattern starting with the 1974-75 surge in materials prices. However, the behavior of investment quantities during the 1974-75 period suggests the exact opposite of a demand-driven boom: After growing 18 percent in 1973, real equipment investment grew only 2 percent in 1974 and fell 10.5 percent in 1975, the largest decline in the period 1959-98 (and a much larger decline than in the deeper recession of the early 1980s). These quantity movements are far more consistent with a negative supply shock.

Finally, there is the question of whether equipment producing industries are, in fact, large enough to have a significant influence on the prices of their intermediate inputs. This question could be answered very easily if each equipment industry used only one intermediate input. In this case, we could compare intermediate input usage for each equipment industry with the total production of that specific input. Since, in reality, each type of equipment requires a number of intermediate inputs, we instead need to calculate a weighted average estimate of how large each equipment producing industry is relative to the supply of these inputs. To construct such a "size" measure for each equipment-producing industry, I used information from the 1992 two-digit Input-Output tables. The size measure for equipment-producing industry $i$ is defined to be

$$
S_{i}=\sum_{k=1}^{N} \omega_{i k} \frac{M_{i k}}{M_{k}}
$$

where $N$ is the number of intermediate inputs, $M_{i k}$ is total purchases by industry $i$ of intermediate input $k, M_{k}$ is total production (for both intermediate and final use) of input 
$k$, and $\omega_{i k}$ is the share of input $k$ in industry $i$ 's materials costs: ${ }^{8}$

$$
\omega_{i k}=\frac{M_{i k}}{\sum_{k=1}^{N} M_{i k}}
$$

This measure is best understood using a simple numerical example. Suppose an industry has two inputs with outlays on each being the same $\left(\omega_{1}=\omega_{2}=0.5\right)$ and the industry demands 10 percent of the total production of input 1 and 70 percent of the total production of input 2. In this case, our measure of size equals $0.5 * 0.1+0.5 * 0.7=0.4$, which implies that shifts in this industry's demand are likely to have a sizeable impact on the weighted-average price of its intermediate inputs.

Table 5 presents the estimates of this size measure for each of our 22 equipment industries. These estimates show that each of the equipment industries, on average, demands a very small proportion of the production of the industries that supply their inputs. The largest estimates, for Autos and Office and Computing Machinery are still below 6 percent. ${ }^{9}$ Thus, if we were looking for good demand instruments for the set of "synthetic" weightedaverage industries that supply their inputs to each equipment producing industry, in each case, the equipment producers would fail John Shea's first criterion, which requires that they demand a high proportion of the supplying industry's output. ${ }^{10}$ As such, it would strain credibility to suggest that more generous tax incentives for these equipment industries could significantly raise the weighted average price of their intermediate inputs.

One can note, though, that the construction method behind the NBER input deflators implicitly assumes that the price of each individual input is the same for all equipment producers (since they are constructed by weighting aggregate deflators for input prices according to each input's share in costs). It is possible, though, that for some equipment producers an increase in demand could result in higher prices for a specific input for those producers, even if the the price of that input is unchanged for all other firms. For example,

\footnotetext{
${ }^{8}$ These calculations were derived in three steps. First, I constructed "industries" based on each of the NIPA equipment categories used in this paper using Table E of Lawson (1997a), which defines each of the NIPA categories in terms of input-output commodities. Second, I used the commodity-by-commodity "use" table in Lawson (1997b) to estimate the total intermediate input usage of each commodity by each equipment type (the $M_{i k} \mathrm{~s}$ ). Third, total commodity output (the $M_{k}$ 's) was taken from Table 2.1 of Lawson (1997a).

${ }^{9}$ If these figures seems too small, one should note that total nominal private expenditures on equipment averaged only 6.6 percent of GDP over our sample.

${ }^{10}$ Shea's cutoff rule required his instruments to represent at least 15 percent of the industry's demand.
} 
suppose that all tractors were constructed using steel supplied by one specific steel mill. In that case, an increase in the demand for tractors could strain production at this steel mill and could possibly raise the price of steel for producers of tractors; this increase, though, would not show up significantly in the NBER input price deflator for tractors. However, if such specificity were important then one would expect to estimate a significant effect of tax incentives on equipment prices, even if one includes the NBER input deflators, and this is not what we observe.

\begin{tabular}{|l|c|l|c|}
\hline 1. Furniture & .008 & 12. Service Ind. Mach. & .005 \\
\hline 2. Fabricated Metals & .005 & 13. Electrical Distrib. & .005 \\
\hline 3. Engines & .003 & 14. Communications & .035 \\
\hline 4. Tractors & .004 & 15. Oth. Electr. Equip & .003 \\
\hline 5. Agric. Machinery & .004 & 16. Trucks and Buses & .033 \\
\hline 6. Constr. Machinery & .005 & 17. Autos & .055 \\
\hline 7. Mining Machinery & .001 & 18. Aircraft & .006 \\
\hline 8. Metalworking Mach. & .008 & 19. Ships & .001 \\
\hline 9. Special Ind. Mach. & .011 & 20. Railroad Equipment & .001 \\
\hline 10. General Ind. Mach. & .010 & 21. Instruments & .009 \\
\hline 11. Office \& Computers & .058 & 22. Other Equipment & .004 \\
\hline
\end{tabular}

Table 5: The Size of Equipment Industries Relative to Their Input Suppliers 


\section{Conclusion}

The effect of tax incentives on capital investment is a very important economic policy issue. Beyond specific policies such as the investment tax credit, understanding the response of investment to tax incentives is crucial for assessing the likely long-run effects of tax reform proposals, many of which stress their beneficial effects on capital formation. Thus, the hypothesis of a steep upward-sloping supply curve for capital equipment, as proposed by Goolsbee, has profound implications for a number of policy debates. This paper has re-examined the evidence on the link between equipment prices and tax incentives and concluded that Goolsbee's result that investment tax incentives drive up equipment prices appears to be spurious. Once one controls for variations in prices of energy and material inputs, there is no evidence that tax incentives affect equipment prices. In fact, the evidence is broadly consistent with a flat supply curve for capital equipment. An important implication of a flat supply curve is that one can only identify the price elasticity of investment demand by examining quantity movements. Thus, the challenge for macroeconomists is to reconcile the macroeconomic evidence of a weak effect of the user cost of capital on investment quantities with microeconomic evidence such as that of Cummins, Hassett, and Hubbard (1994) which suggests a large effect.

\section{References}

[1] Bartelsman Eric J. and Wayne Gray (1996). The NBER Manufacturing Productivity Database, NBER Technical Working Paper No. 205.

[2] Bruno, Michael (1984). "Raw Materials, Prices, and the Productivity Slowdown", Quarterly Journal of Economics, 1-30.

[3] Clark, Peter K. (1992). "Tax Incentives and Equipment Incentives", Brookings Papers on Economic Activity, 1, 317-339.

[4] Cummins Jason, Kevin Hassett, and R. Glenn Hubbard (1994). "A Reconsideration of Investment Behavior Using Tax Reforms as Natural Experiments", Brookings Papers on Economic Activity, 2, 1-59.

[5] Goolsbee, Austan (1998). "Investment Tax Incentives, Prices, and the Supply of Capital Goods", Quarterly Journal of Economics, 121-148. 
[6] Gravelle, Jane (1994). The Economic Effects of Taxing Capital Income, Cambridge: MIT Press.

[7] Greenwood, Jeremy, Zvi Hercowitz, and Per Krussell (1997). "Long-Run Implications of Investment-Specific Technological Change", American Economic Review, 342-62.

[8] Hassett, Kevin and R. Glenn Hubbard (1998). Are Investment Tax Incentives Blunted By Changes in Prices of Capital Goods?, NBER Working Paper No. 6676.

[9] Lawson, Ann M. (1997a). "Benchmark Input-Output Accounts for the U.S. Economy, 1992: Make, Use, and Supplementary Tables", Survey of Current Business, November, 36-82.

[10] Lawson, Ann M. (1997b). "Benchmark Input-Output Accounts for the U.S. Economy, 1992: Requirements Tables", Survey of Current Business, December, 22-47.

[11] Shea, John (1993). "Do Supply Curves Slope Up?", Quarterly Journal of Economics, $1-32$.

[12] U.S. Department of Commerce, Bureau of Economic Analysis (1993). Fixed Reproducible Tangible Wealth in the United States, 1925-1989, Washington DC: U.S. Government Printing Office.

[13] U.S. Department of Commerce, Bureau of Economic Analysis (1998a). National Income and Product Accounts of the United States, 1929-94: Volume 2, Washington DC: U.S. Government Printing Office.

[14] U.S. Department of Commerce, Bureau of Economic Analysis (1998b). "National Income and Product Accounts Tables", Survey of Current Business, August, 36-118.

[15] U.S. Department of Treasury, Internal Revenue Service (1998a). Publication 534: Depreciating Property Placed in Service Before $198 \%$.

[16] U.S. Department of Treasury, Internal Revenue Service (1998b). Publication 946: How to Depreciate Property. 


\section{A SIC Codes for Equipment Producers}

\begin{tabular}{|l|l|}
\hline Equipment Class & SIC Codes \\
\hline 1. Furniture & 25 \\
\hline 2. Fabricated Metals & 34 \\
\hline 3. Engines & 351 \\
\hline 4. Tractors & 3537 \\
\hline 5. Agric. Machinery & 352 \\
\hline 6. Constr. Machinery & 353 ex. 3537, 3532-3 \\
\hline 7. Mining Machinery & $3532-3$ \\
\hline 8. Metalworking Mach. & 354 \\
\hline 9. Special Ind. Mach. & 355 \\
\hline 10. General Ind. Mach. & 356 \\
\hline 11. Office \& Computers & 357 \\
\hline 12. Service Ind. Mach. & 358 \\
\hline 13. Electrical Dist. & 361 \\
\hline 14. Communications & 366 \\
\hline 15. Oth. Electr. Equip. & 36 ex. 361, 366 \\
\hline 16. Trucks and Buses & 3711 \\
\hline 17. Autos & 3711 \\
\hline 18. Aircraft & 372 \\
\hline 19. Ships & 373 \\
\hline 20. Railroad Equipment & 374 \\
\hline 21. Instruments & 38 \\
\hline 22. Other Equipment & 359 \\
\hline
\end{tabular}

Not all of the equipment classes could be exactly matched up with an SIC code and so a couple of these matches are based on informed guesses. A full description of what types of equipment are covered by each category is contained in Appendix E of Benchmark Input-Output Accounts of the United States, 1992, available at http://www.bea.doc.gov/bea/an1.htm. 


\section{B Construction of the Full Tax Term}

The full tax term was defined to be

$$
\left[\frac{1-I T C-(1-\theta * I T C) \tau z}{1-\tau}\right]
$$

where $\tau$ is the marginal corporate tax rate, $z$ is the present discounted value of depreciation allowances, ITC is the investment tax credit, and $\theta$ is the proportion of the investment tax credit that needs to be deducted from the depreciation base.

Table 6 displays the investment tax credit for each type of equipment, taken from Gravelle (1994). The parameter $\theta$ was set equal to zero for all years apart from 1962 (for which it was set equal to 1) and the period 1982-86 (for which it was set to 0.5). The present discounted value of depreciation allowances was calculated based on the service life assumptions shown in Table 7, again largely taken from Gravelle. Prior to 1981, the income stream of depreciation allowances for each type of equipment was calculated based on the assumption that firms claimed allowances using the double declining balance method switching to the so-called "Sum of the Year's Digits" method. For 1981-86, the stream of allowances for each type of equipment was taken directly from IRS Publication 534, while the calculations for 1987-1994 were taken from IRS Publication 946. Present values of these depreciation allowances for each year's tax code were calculated using that year's value for the mean BAA corporate bond rate. 


\begin{tabular}{|l|l|l|l|l|l|l|l|}
\hline Equipment Class & $59-61$ & $62-68$ & $69-70$ & $71-73$ & $74-80$ & $81-86$ & $87-97$ \\
\hline 1. Furniture & 0 & 7 & 0 & 7 & 10 & 10 & 0 \\
\hline 2. Fabricated Metals & 0 & 7 & 0 & 7 & 10 & 10 & 0 \\
\hline 3. Engines & 0 & 5.1 & 0 & 5.6 & 10 & 10 & 0 \\
\hline 4. Tractors & 0 & 6 & 0 & 6 & 9 & 10 & 0 \\
\hline 5. Agric. Machinery & 0 & 7 & 0 & 7 & 10 & 10 & 0 \\
\hline 6. Constr. Machinery & 0 & 4.6 & 0 & 4.6 & 6.6 & 10 & 0 \\
\hline 7. Mining Machinery & 0 & 7 & 0 & 7 & 10 & 10 & 0 \\
\hline 8. Metalworking Mach. & 0 & 6 & 0 & 6 & 8.6 & 9.4 & 0 \\
\hline 9. Special Ind. Mach. & 0 & 7 & 0 & 7 & 10 & 10 & 0 \\
\hline 10. General Ind. Mach. & 0 & 6.4 & 0 & 6.4 & 9.1 & 9.6 & 0 \\
\hline 11. Office \& Computers & 0 & 7 & 0 & 7 & 10 & 10 & 0 \\
\hline 12. Service Ind. Mach. & 0 & 7 & 0 & 7 & 10 & 10 & 0 \\
\hline 13. Electrical Dist. & 0 & 4.8 & 0 & 5.7 & 10 & 10 & 0 \\
\hline 14. Communications & 0 & 4.6 & 0 & 5.2 & 10 & 10 & 0 \\
\hline 15. Oth. Electr. Equip. & 0 & 7 & 0 & 7 & 10 & 10 & 0 \\
\hline 16. Trucks and Buses & 0 & 4.6 & 0 & 4.6 & 6.6 & 10 & 0 \\
\hline 17. Autos & 0 & 2.3 & 0 & 2.3 & 3.3 & 6 & 0 \\
\hline 18. Aircraft & 0 & 7 & 0 & 7 & 10 & 10 & 0 \\
\hline 19. Ships & 0 & 7 & 0 & 7 & 10 & 10 & 0 \\
\hline 20. Railroad Equipment & 0 & 7 & 0 & 7 & 10 & 10 & 0 \\
\hline 21. Instruments & 0 & 7 & 0 & 7 & 10 & 10 & 0 \\
\hline 22. Other Equipment & 0 & 7 & 0 & 7 & 10 & 10 & 0 \\
\hline
\end{tabular}

Table 6: Investment Tax Credit Rates 


\begin{tabular}{|l|l|l|l|l|l|}
\hline Equipment Class & $59-61$ & $62-70$ & $71-80$ & $81-86$ & $87-97$ \\
\hline 1. Furniture & 14 & 10 & 8 & 5 & 7 \\
\hline 2. Fabricated Metals & 25 & 18 & 14 & 5 & 7 \\
\hline 3. Engines & 29 & 22 & 18 & 5 & 7 \\
\hline 4. Tractors & 12 & 9 & 7 & 5 & 5 \\
\hline 5. Agric. Machinery & 14 & 10 & 8 & 5 & 7 \\
\hline 6. Constr. Machinery & 10 & 7 & 5 & 5 & 5 \\
\hline 7. Mining Machinery & 16 & 11 & 9 & 5 & 5 \\
\hline 8. Metalworking Mach. & 14 & 9 & 8 & 5 & 7 \\
\hline 9. Special Ind. Mach. & 16 & 11 & 9 & 5 & 7 \\
\hline 10. General Ind. Mach. & 14 & 12 & 10 & 5 & 7 \\
\hline 11. Office \& Computers & 10 & 7 & 7 & 5 & 7 \\
\hline 12. Service Ind. Mach. & 17 & 12 & 10 & 5 & 7 \\
\hline 13. Electrical Dist. & 22 & 17 & 14 & 5 & 7 \\
\hline 14. Communications & 19 & 14 & 12 & 5 & 5 \\
\hline 15. Oth. Electr. Equip. & 16 & 11 & 9 & 5 & 7 \\
\hline 16. Trucks and Buses & 10 & 7 & 5 & 5 & 5 \\
\hline 17. Autos & 4 & 3 & 3 & 3 & 5 \\
\hline 18. Aircraft & 16 & 12 & 9 & 5 & 5 \\
\hline 19. Ships & 28 & 20 & 16 & 5 & 10 \\
\hline 20. Railroad Equipment & 26 & 19 & 15 & 5 & 7 \\
\hline 21. Instruments & 18 & 13 & 10 & 5 & 7 \\
\hline 22. Other Equipment & 15 & 11 & 9 & 5 & 7 \\
\hline
\end{tabular}

Table 7: Tax Service Lives 